\title{
The Determinants Of World Islamic Banks Efficiency: Empirical Analysis Using A Non Parametric Approach
}

Olfa Nafti, University of Manouba, Manouba, Tunisia Salem Lotfi Boumediene, Montana State University Billings, Montana, USA

Slim Khouaja, University of Tunis, Tunis, Tunisia

Wassim Ben Ayed, University of Tunis, Tunis, Tunisia

\begin{abstract}
The purpose of this paper is to analyze the efficiency of Islamic banks operating in different countries, over the period 2006-2009.

We applied a non-parametric approach, or a Data Envelopment Analysis (DEA), that utilizes both the constant returns to scale (CRS) and the variable returns to scale (VRS) assumptions to offer measures of the technical and scale efficiency. The outcomes reveal a considerable degree of dispersion of technical efficiency between banks within the sample of the year-to-year basis. To inspect the determinants of efficiency, we apply the panel regression analysis. In fact, we used panel regression analysis in order to explain the variation in the dependent variable (calculated efficiencies) by a set of independent variables, such as banks size, asset quality, management capability, liquidity, sensitivity to markets risks, and capitalization.

We find that banks with higher liquidity and a good management capability are more likely to operate at higher levels of technical efficiency. In addition, the results show that size, seem to contribute negatively to the evolution of efficiency scores of Islamic banks operating in the world.
\end{abstract}

Keywords: Efficiency; Islamic Banking; Data Envelopment Analysis (DEA); Panel Regression

\section{INTRODUCTION}

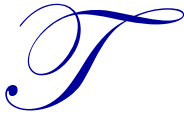

he world global crisis began with difficulties met by the households to pay off the credits. It brought to light the fragility of a financial system and economic dysfunction. In the same time, it woke the interest of the authorities to look for alternative sources of funding by respecting the business ethics.

As such, The Islamic banking occupied particularly an important place with its financial stability, which characterized banks during this period. It appeared as a viable solution of the analysts, which has many things to offer. Hasan \& Dridi (2010) showed that the global crisis fills up the opportunity to prove their resilience year; it also highlighted the need to address importing challenges.

Many investigations suggest that Islamic banks fared differently from traditional banks during the crisis because of the adherence of the Shariah principles, which prohibits "immoral" investments that affected the conventional system. Hassen (2010) suggests that Islamic banking system strikes a balance between flexibility and oversight. The proponent of Islamic banking system expects that credit crunch could not happen in the Islamic financial institutions. Because this system operates based on a partnership between the clients and the banks, there is a social agreement within the Islamic banking and finance.

Today, Islamic banking is witnessing strong global growth and leads as a competitor of the traditional banking. According to Zied \& Pluchart (2006) several reasons can explain this success. First, the influx of "petrodollars" due 
to the increase of hydrocarbon prices. Second, the development of the Moslem communities in the western metropolises. Third, the progress of the micro-credit in developing countries, and finally, the reaction against the international financial capitalism and the resurgence of the Muslim fundamentalism.

Since the creation of the first Islamic financial institutions in the fifties, the industry has experienced a tremendous evolution. Islamic banking exceeded the borders of Moslem countries by settling down in all the regions of the world. This evolution allowed this system to be a viable system. Although it was initially established to serve the needs of the Moslem population, the Islamic banks knew a vast network, which can support numerous projects, which aim at the growth of the economy.

Islamic banks have been evaluated since the beginning of the crisis with the aim to highlight principal sources of resilience and the opportunities of growth. According to a recent International Monetary Fund (IMF) study, Hasan \& Dridi, (2010), "Islamic banks behaved better than the traditional ones in 2008 in terms of profitability, credit and asset growth". Parashar \& Venkatesh (2010) found that the six Islamic banks included in the study have performed better than the six traditional banks during 2006-2009.This results indicates that Islamic banks delivered better in profitability and were higher capitalized than the traditional banks over a four-year period, even though they suffered in the period of crisis in terms of lowering of CAR, Equity/Total assets and ROAE. This confirms the results found by Hasan \& Dridi (2010). However, such an analysis does not give reliable results regarding the viability and the strength of the banking system in the sense that it does not provide adequate control of all variables that characterize the financial system where Islamic banks are operating.

Actually, this industry operates in a sector more and more integrated through reforms in the global financial industry. That is why banks must take care of their levels of efficiency as well as their competitiveness in order to improve their management and their operational planning. Many investigations have examined the development of Islamic banking. Ackermann \& Jacobs (2008) showed that the discovery of the oil wealth in the Middle East during the 1970s implemented competent infrastructure for benefiting the growth of Islamic banking. They found that religious reasons have encouraged the development of Islamic finance in South Africa.

Imam \& Kpodar (2010) investigated the determinants of the pattern of Islamic bank diffusion around the world using country-level data for 1992-2006. The investigation depicts that income per capita, share of Muslims in the population and status as an oil producer are related to the development of Islamic banking. Interest rates have a negative impact on Islamic banking, which indicate the implicit benchmark for them. Haniffa \& Hudaib (2010) examined the political and socio-economic situation of the evolution of Islamic finance in three different periods. They showed that the growth of Islamic finance, to become part of mainstream global finance, was not driven purely by sacred intentions of fulfilling religious obligations but also a powerful political-economic weapon for control. They found that Islamic finance had to undergo transformation in order to become acceptable as part of the global finance community.

Vayanos et al. (2008) analyzed the drivers of growth behind Islamic banking and the changing competitive landscape, and examined potential sources of differentiation for Islamic banks, as well as the challenges that are unique to these banks. Results showed that the market for Islamic banking is substantial. However, as the competitiveness increases, the leaders' banks will be those that will offer differentiated services and address the challenges related to Islamic finance.

Van Schaik (2001) showed that the main challenge for Islamic banking is to find more successful methods of mediumand long-term financing, based on Profit and Loss Sharing (PLS). The other problems are less complex and are believed to be solved in the course of time. More serious is the problem with PLS-financing. The development of Islamic money and capital markets and the securitization of project financing will alleviate the problem. Others studies have examined the financial development of Islamic banking. They are based on financial and conventional ratio (Ahmad \& Noor, 2011; Austay \& Izhar, 2007; Haron, 2004; Saleh \& Zeitun, 2006) and/or using parametric or nonparametric methods (Yudistira, 2004; Viverita et al., 2007; Brown \& Skully, 2003; Sufian, 2007).

Surprisingly, seen the development of the banking industry, there are only a few papers, which studied the determinant of Islamic banks' efficiency across the world (Kablan, 2011) using non-parametric methods. The existing papers analyzed the scores of the efficiency of banks settled in one or several countries. 
Given this situation, research on efficiency and determinants are of great importance. A firm is taken to be more efficient than another firm, which operates in the same sector if it produces relatively more output from the same set of inputs. So, such a study is necessary to give information to managers to improve their efficiency levels within the banking system and to addressing the needs of different stakeholders. Then, this type of investigations will exhibit the development of Islamic industry in a mixed banking system to improve levels of efficiency. Finally, much less research has been conducted in the area of Islamic banking; it is important for these types of banks to be studied and to show at the same time that factors impact the efficiency.

The aim of this research consists of examining and evaluating the efficiency of banks: The first step is to study the efficiency of Islamic banks. In a second step, we will study the effect of variables included in the study on the efficiency i.e. asset quality, management capability, size, capitalization, liquidity, sensitivity to market risk.

This paper employs non-parametric methods, Data Envelopment Analysis (DEA) to study the efficiency of 30 banks Islamic in different countries over the 2006-2009 period. Then, we will discuss the change of level of efficiency in the pre-crisis period, crisis period, and post-crisis period of the global crisis. Third, by applying the DEA method to the panel data over time, some variables, which characterize the ethics system will be estimated in the second step. The results allow us to examine what factors are important in improving the efficiency of Islamic banks.

In the first part of this paper, we present a set of academic papers that have studied the efficiency of Islamic banks. In the second part, we will present the methodology. In the third part, we will present the results and their interpretations. In the last part, we will conclude our research.

\section{AN OVERVIEW OF THE FINANCIAL LITERATURE}

In the past decades, improvements in the Islamic banking took place. Many occidental countries (i.e. UK, USA) encourage this type of financing. That created a need for accessing the information to evaluating Islamic banks operating in the market and encouraged researchers to examine the development of Islamic finance. Cihajk \& Hesse (2008) studied the possible channels through which Islamic finance could impact global financial stability.

The literature examining Islamic institutions has expanded rapidly in recent years. Several studies assessed Islamic bank performance based on financial and management ratio. But this analysis of financial indicators may be an obstacle in the sense that the number of indicators can prevent easy interpretations of results.

A first stream of research is looking at the performance of Islamic banks. They adopted the conventional financial ratio to evaluate factors that have a significant impact on banks' profitability. The empirical studies have focused on different conventional ratios like the Returns On Assets (ROA), Returns On Equity (ROE), and net interest margins. It has traditionally examined the impact of bank-specific factors such as liquidity, risk, market power, size and capitalization on bank performance. For instance, Ahmad \& Noor (2011) investigates the profitability of 78 Islamic banks in 25 countries for the period of 1992-2009. Results show that profit efficiency is positive and statistically significant with operating expenses against the assets, equity, high-income countries and non-performing loans against total loans. According to the authors, "Interestingly, the empirical results show that the most profitable banks are those that have higher operating expenses against asset, more equity against asset and concentrated at high-income countries that show close relationship between monetary factors in determining Islamic banks profitability. The findings for 1998 Asian Financial Crisis and 2008 Global Financial Crisis are negative and imply that Islamic banks' profitability has not been impacted during Asian and Global Financial crises".

Other authors were interested in the study of regions such as the Gulf Country Council (CCG). For that purpose, Moussawi \& Obeid (2010) proposed, "a method to assess the productive performance of Islamic banks operating in the GCC region, over the period of 2005-2008". Thus, they evaluated the productive performance of Islamic banks with the technique of productive efficiency proposed by Farrell (1957). They used the DEA to break down the productive efficiency into technical efficiency, allocation efficiency, and cost efficiency. The application of this technique on a sample of 23 Islamic banks reveals that the technical inefficiency and allocative inefficiency increased bank costs, on average, by about $14 \%$ and $29 \%$ respectively". In addition, the results showed that "internal and external factors seem to contribute significantly to the evolution of efficiency scores of Islamic banks operating in the GCC region." 
The MENA was so present in the literature with the study of Sufian \& Noor (2009), investigated the efficiency of the Islamic banking in 16 MENA and Asian countries during 2001-2006. The efficiency estimates of individual banks are assessed using the non-parametric Data Envelopment Analysis (DEA) method. According to the authors, the results show the MENA Islamic banks have higher mean technical efficiency compared to the Asian Islamic banks. The results also demonstrate that banks from the MENA region were the most efficient banks by dominating the top part of the efficiency frontier over the period.

\subsection{Single Country Studies}

Sufian (2007) adopted the DEA method to examine the efficiency in domestic and foreign Islamic banks in Malaysia between 2001 and 2004. He provided evidence that these banks improved their efficiency slightly in 2003 and 2004. Nevertheless, Malaysian Islamic banks are found marginally more efficient than non Malaysian ones. Besides Islamic bank's profitability is significantly and positively correlated to three different types of efficiency: technical, pure technical and scale efficiencies. This study set out to provide empirical evidence of Islamic banks' efficiency in Malaysia for the years 1997-2003. For analysis purposes, the annual report of two full-fledged Islamic banks, 20 Islamic windows, and 20 traditional banks were used. The results showed that for Islamic banking industry, the overall average efficiency has increased. The study also showed that the full-fledged Islamic banks were more efficient that the Islamic windows.

Saaid et al. (2003) investigate the X-efficiency (technical and allocative) of the Islamic banks in Sudan using the basic Stochastic Frontier Approach (SFA). Their empirical result shows a low levels of X-efficiency for the sample of banks studied. Consequently, the Sudanese Islamic banks were not optimizing their inputs usage. Onour \& Abdalla (2011) employed several efficiency measures and productivity changes using DEA to investigate efficiency performance of Islamic banks in Sudan. Results showed that, "among twelve banks included in the sample, only two banks (the largest bank in the group which is government owned, and middle-sized, private bank) score technical efficiency level (i.e. scale and pure technical efficiency). While the smallest bank in the group (private owned), score pure technical efficiency (i.e., managerial efficiency), but scale inefficient. This result adds additional evidence, in the existing literature, that ownership (government versus private) is not a constraint of managerial and scale efficiency and that the bank's size is an important factor for scale efficiency".

According to the previous studies, we tried to bring to light a set of variables which characterize the Islamic financial system and which can explain the variations perceived at the level of the efficiency. This study aims cover a large range of countries. We will examine the change in efficiency levels and we will analyze the determinants of their efficiencies. We will hold only the variables, which are available during our period of study and that seem better characterize the banking landscape.

Izhar \& Asutay (2007) analyzed the performance of Bank Muamalat Indonesia (BMI) in terms of its ROA. Utilizing regression analysis, they discovered that financing activities generated most profit. However, service activities did generate significant profit for BMI. In addition, during 1996-2001, short-term based financing was the most part of BMI's. The conclusion of the paper confirms the hypothesis of positive relationship between inflation and profitability measure. Badreldin (2009) adapts a currently applied ROE Analysis Tool used in traditional banks, to the established model of Islamic Banks and tested its applicability and evaluates its usefulness. According to Badreldin (2009), "The findings suggest that such a model would be quite successful for use in Islamic banks and would offer much better analysis and basis of comparison within the Islamic financial system. It also suggest that much of the previously measured performance of Islamic Banks is unsound and should be revised for accuracy and reliability because of the flawed methods used for measurement in the first place".

Other investigations have focused on the examination of bank efficiency; the existing works in this area divide into two groups. The first Group used parametric methods (stochastic frontier) and the second group used a non-parametric approach. The use of efficiency scores allows going beyond the criticism of traditional methods. It helped draw relevant conclusions and the height of a proper analysis of the financial situation to be acclaimed by the general public. Research on the efficiency of Islamic banks is interested in a specific country. Studies on efficiency have focused whether on a panel of countries (MENA, GCC) and on a particular country (such as Malaysia, Pakistan, Indonesia, and Sudan). 


\subsection{Panel Country Studies}

Yudistira (2003), in his study of 18 Islamic banks over the period 1997-2000, utilized the DEA to evaluate the 'technical efficiency', the 'pure technical efficiency', and the 'scale efficiency' of Islamic banks. The intermediation approach is adopted in order to define Islamic banks' input-output variables. The results of the study show that there is a small (just over 10\%) inefficiency across 18 Islamic banks, which is considerable as compared to many conventional counterparts. He also found that global crisis in 1998-1999 has badly affected the performance of Islamic banks. In addition, small and medium sized Islamic banks faced diseconomies of scale, suggesting that M\&A should be encouraged. Finally, publicly listed Islamic banks are found to be less efficient compared to non-listed ones.

Kablan \& Yousfi (2011) analyzed Islamic bank efficiency over the period 2001-2008. They found that they were efficient at $92 \%$. The level of efficiency varies according to the region where they operate. Asia displays the highest score (96\%). Indeed, countries like Malaysia made amends to allow these banks to cope better with the existing financial system displaying the highest scores. On the other hand, countries with Islamic banking system do not certainly exhibit efficiency scores higher than the average. On the other hand, results show that the subprime crisis seems to have impacted those banks indirectly. Finally, market power and profitability have a positive impact on Islamic banks' efficiency, while it is the opposite for their size. The latter implies that they do not profit from scale economy, maybe because of the specificity of Islamic financial products.

Using Malmquist DEA methodology, Viverita et al. (2007) examined the efficiency change of Islamic banks over 1998-2002 period on a country and regional basis. Results show that Indonesia and Yemen proved to be the most improved countries. Asia was the best region. Brown (2003) analyzed the performance of Islamic banks in different countries. Iran, Brunei and Yemen constantly have the most efficient markets and Indonesia and Sudan the least cost efficient. Both Iran and Brunei have an Islamic banking markets above $40 \%$, whereas Yemen's Islamic banks have grown in importance from $9.4 \%$ in 1998 to $19.2 \%$ in 2001. Besides, the results show that the market share of Islamic banks is generally increasing in most countries and many of these countries have large Muslim populations. Only Brunei and Iran Islamic banks have significant market share. Therefore, the potential growth of Islamic banks is colossal.

\section{METHODOLOGY}

A first aim of this research is to study the efficiency of the Islamic banks during the four years. In a second step, we will analyze the impact of these variables. To answer our first aim, we are going to resort to the DEA method to analyze the scores. Then, we will answer to the second aim by using the linear regression to analyze the impact of the variables included in the study.

\subsection{Data Envelopment Analysis (DEA)}

In our study, the DEA approach is used to estimate the levels of efficiency of Islamic banks over the period 20062009. The purpose of using DEA in this study is to measure the comparative efficiency of several homogeneous decision-making units by aggregating multiple performance indicators into a single framework for identifying best practice.

The envelopment form of the input-oriented Constant Returns to Scale (CRS) DEA model following CCR (Charnes et al., 1978) for the $\mathrm{i}$-th firm is specified as:

$\operatorname{Min} \theta, \lambda$

Subject to: $\quad-y_{i}+Y \lambda \geq 0, i$

$\theta x_{i}-X \lambda \geq 0, i$

$\lambda \geq 0$,

Where $\theta$ is the input technical efficiency score having a value $0 \leq \theta \leq 1$. If the $\theta$ value is equal to one, this indicates that the region is on the frontier. The vector $\lambda$ is an $N x l$ vector of weights that defines the linear combination of the peers of the i-th firm. According to Banker et. al (1984), the linear programming problem needs to be solved $N$ times 
and a value of $\theta$ is provided for each firm in the sample. The Variable Returns to Scale (VRS) DEA model is defined by adding the constraint:

$$
\sum\left(\lambda_{i}\right)=1
$$

Because the VRS -DEA is more flexible and encloses the data in a more stable way than the CRS-DEA, the VRS-TE score is equal to or greater than the CRS or 'overall' technical efficiency score. In fact, under the VRS model an efficiency score of less than unity of a company is considered as neither technically efficient nor scale efficient. Otherwise, if the organization receives a unit efficiency score, it is pure technically efficient but may not be scale efficient.

The scale efficiency (SE) of the i-th firm is computed as:

$$
S E=\frac{T E(C R S)}{T E(V R S)}
$$

Where $S E=1$ implies scale efficiency and $S E<1$ indicates scale inefficiency. One can note that scale inefficiency can be due to the existence of either Increasing or Decreasing returns to Scale (IRS or DRS).

According to Coelli et al. (1998), to identify the nature of Returns to Scale, the CRS efficiency score is compared with VRS efficiency score. For a given entity (for example port, bank, etc.), if the VRS score equals the CRS score, the entity is said to be operating at CRS. If the scores are different, a further step is needed to determine whether the entity is operating at IRS or DRS by using the Non-Increasing Returns to Scales (NIRS) DEA model. In this case, if the VRS score equals the NIRS score, the entity is said to be operating at DRS. On the other hand, if the VRS score is different from the NIRS score than the entity is said to be operating at IRS ().

\subsection{Panel Regression Analysis}

DEA in this investigation is computed in a first stage to calculate score's efficiency. In a second stage of this study, scores are modeled via a panel regression technique to analyze the factors affecting the efficiency. In this study, we adopt the following model:

$$
Y_{i t}=f\left(A S S E T_{-} Q L T, M G T_{-} Q C T, L N T A, L A R, K A, S E_{-} M K T\right)
$$

Where, $Y$ is the score of the efficiency of the $\mathrm{j}^{\text {th }}$ bank in period t obtained from DEA under the intermediation approach. $A S S E T \_Q L T, M G T \_Q C T, L N T A, L A R, K A, S E \_M K T$ is a set of Islamic bank specific characteristics.

$$
\begin{aligned}
& Y_{i t}=\alpha_{i t}+\alpha_{1} A_{S S E T_{Q L T}}+\alpha_{2} M G T_{Q C T_{i t}}+\alpha_{3} L N T A_{i t}+\alpha_{4} L A R_{i t}+\alpha_{5} K A_{i t} \\
& +\alpha_{6} S E_{-} M K T_{i t}+\varepsilon_{i t}
\end{aligned}
$$

\subsection{Specification Of Bank Inputs, Outputs, And Data}

In the banking literature, there is a great disagreement among researchers about what constitute inputs and outputs of the banking industry (Casu, 2002; Sathye 2003). Three different approaches appear in the literature regarding the measurement of inputs and outputs of a bank. The production and intermediation approaches (Sealey \& Lindley, 1977) and more recently, the revenue or profit oriented approach.

Under the first approach, initiated by Benston (1965), researchers confirmed that banks as production units use capital and human resources to produce various types of loan accounts and deposits. Under this vision, the number of employees and equity represents the inputs. However, the outputs are represented by all the services, and they are measured in a number of accounts managed by the banks.

On the other hand, the intermediation approach views the banks as in intermediary between savers and borrowers using deposits together with purchased inputs to produce various categories of bank assets. Therefore, inputs are deposited along with labor and physical capital. Outputs are represented by total loans and securities (Sealey \& Lindley, 1977). 
More recently, Sufian and Habibullah (2009), Drake et al. (2006) proposed the revenue approach in DEA. The revenue approach (or income based approach) considers the final objective of banks is to generate revenue from the total cost incurred resulting from running the bank. Accordingly, it defines banks» output as total revenue (interest and noninterest income) and inputs as the total expenses (interest and non-interest expenses).

In our study, given the difficulty of collecting private information and given the lack of information (number of client accounts, the number of credits granted by banks, characteristic of the banking system, etc.), we will adopt the intermediation approach. In practice, the intermediation approach is the technique most widely used by researchers. In fact, Berger \& Humphrey (1997) suggested that the intermediation approach is best suited for analyzing bank level efficiency, whereas the production approach is appropriate for measuring branch level efficiency.

The efficiency frontier is constructed by using 30 Islamic banks operating in the different countries in the world during the period 2006-2009 yielding 120 bank-year observations. The data are collected from annual reports and financial statements after consulting the official websites of the banks studied. Two inputs and three outputs are used.

As inputs, we used the total deposits $\left(\mathrm{X}_{1}\right)$ and the total assets $\left(\mathrm{X}_{2}\right)$ while as outputs, we used the total Investment $\left(\mathrm{Y}_{1}\right)$, the total loans $\left(\mathrm{Y}_{2}\right)$ and the total income $\left(\mathrm{Y}_{3}\right)$. This approach was used by Sufian et al. (2008).

Independent variables are used to clarify the variations of bank efficiency. Six independent variables will be analyzed in this study namely, size (LNTA), liquidity ratio (LAR), the quality of assets(ASSET_QLT), management capability (MGT_QCT), sensitivity to market risk (SE_MKT). The ratio of capital to total assets (KA) is employed to evaluate the relationship between efficiency and risk-taking propensity in which a higher ratio implies a higher risk propensity. All variables are converted into US dollars using the end of year market value in order to take into account the macroeconomic differences across countries during the period of the study.

Table 1 presents the independent variables and their description, measures and their hypothesized relationship with bank efficiency.

Table 1. Variables Used in the Regression Models

\begin{tabular}{|c|c|c|c|}
\hline Variable & Description and & Measures & $\begin{array}{l}\text { Hypothesized Relationship } \\
\text { With Efficiency }\end{array}$ \\
\hline ASSET_QLT & measure of asset quality & $\begin{array}{l}\text { Total Loan Loss Provisions divided } \\
\text { by Total Loans. }\end{array}$ & $+/-$ \\
\hline MGT_QCT & a measure of management capability & Operating Expenses by Net Income & $+/-$ \\
\hline LNTA & the size of the bank & Natural Logarithm of Total Assets & $+/-$ \\
\hline LAR & measure of liquidity & Total Loan divided by Total Asset & $+/-$ \\
\hline SE_MKT & $\begin{array}{l}\text { a measure for sensitivity to market } \\
\text { risk }\end{array}$ & $\begin{array}{l}\text { Off Balance Sheet Items / Total } \\
\text { Assets }\end{array}$ & $+/-$ \\
\hline KA & $\begin{array}{l}\text { analyze the relationship between } \\
\text { efficiency and risk taking propensity }\end{array}$ & $\begin{array}{l}\text { Total shareholders' equity over total } \\
\text { assets }\end{array}$ & $+/-$ \\
\hline
\end{tabular}

\section{RESULTS AND ANALYSIS}

In this part, we will discuss the Technical Efficiency (TE) change of the thirty Islamic banks assessed by the nonparametric DEA method and its decomposition into pure technical efficiency and scale efficiency for each year under analysis. In case of existence of scale inefficiency, we will attempt to provide proof concerning the nature of the Returns to Scale (RS) for each bank. Then, to justify results obtained under the DEA approach, a panel regression analysis is used to relate bank efficiency to set of Islamic bank characteristics. It means that the efficiency scores obtained from the DEA model were used in a second stage as dependent variables, considering the CRS input-oriented model. The CRS model was chosen for its high accuracy in discriminating efficiency. 


\subsection{Descriptive Statistics of Inputs and Outputs}

Table 2 presents the descriptive statistics of the inputs and output employed in the study. On average all the inputs and output has increased over the years during the period of study.

Table 2. Descriptive Statistics for the Inputs and Outputs Variables

\begin{tabular}{|c|c|c|c|c|c|c|}
\hline \multirow[b]{2}{*}{ Year } & & \multicolumn{3}{|c|}{ Inputs } & \multicolumn{2}{|c|}{ Outputs } \\
\hline & & Deposit & Asset & Income & Loans & Investment \\
\hline \multirow{4}{*}{2006} & Mean & $3,904,000$ & 5.340 .887 & $457,903.7$ & $3,034,724$ & 781,783 \\
\hline & Stand. Dev. & $5,441,937$ & $7,441,777$ & $738,724.5$ & $5,132,451$ & $1,076,654$ \\
\hline & Minimum & 1,500 & 2,590 & 237,885 & 865 & 2,195 \\
\hline & Maximum & $20,687,543$ & $29,774,147$ & 2792608 & $25,077,693$ & $3,825,040$ \\
\hline \multirow{4}{*}{2007} & Mean & $4,572,956$ & $7,056,642$ & $422,827.5$ & $3,904,455$ & $1,269,190$ \\
\hline & Stand. Dev. & $7,515,849$ & $10,300,700$ & $721,595.8$ & $6,720,717$ & $2,113,497$ \\
\hline & Minimum & 1,710 & $2,923.675$ & 271.955 & 977.045 & 4,620 \\
\hline & Maximum & $27,090,000$ & $37,590,686$ & $3,025,379$ & $31,574,900$ & $8,407,800$ \\
\hline \multirow{4}{*}{2008} & Mean & $5,242,161$ & $7,950,336$ & $438,461.4$ & $4,802,294$ & $1,320,069$ \\
\hline & Stand. Dev. & $8,170,150$ & $11,100,700$ & $733,023.7$ & $7,980,345$ & $2,265,760$ \\
\hline & Minimum & 1,554 & 2,640 & 255.416 & 941.8 & $4,144.8$ \\
\hline & Maximum & $31,135,148$ & $44,036,257$ & $3,084,186$ & $38,448,941$ & $10,6023,000$ \\
\hline \multirow{4}{*}{2009} & Mean & $4,171,908$ & $8,688,634$ & $449,877.2$ & $5,522,249$ & $1,367,850$ \\
\hline & Stand. Dev. & $6,500,738$ & $12,100,100$ & $782,250.4$ & $8,974,923$ & $2,227,338$ \\
\hline & Minimum & $1,661.2$ & 2,872 & 248 & 560 & 0 \\
\hline & Maximum & $30,300,000$ & $51,218,919$ & $3,451,588$ & $44,612,102$ & $9,552,000$ \\
\hline
\end{tabular}

Note that $Y_{1}$ is the total investment (investment securities held for trading, investment securities available for sale, and investment securities held to maturity). $Y_{2}$ is total loans, (loans to customers and other banks). $Y_{3}$ is the total income (income derived from investment of depositors' funds and other income from Islamic banking operations). $\mathrm{X}_{1}$ is total deposits (deposits from customers and other banks), and $\mathrm{X}_{2}$ is total Assets (Source: Banks Annual Reports and authors own calculations)

The mean scale efficiency during the first year of study (2006) of the whole sample is $100 \%$, which means that all Islamic banks are operating at the optimal scale. During the remaining periods (i.e. 2007, 2008, 2009), results show that banks are not operating at the optimal scale. This scale inefficiency may be a source of overall inefficiency.

It is clear from Table 3 that during the period of study, the Islamic banks have exhibited a mean technical efficiency of $68 \%$. These results suggest that the Islamic banks could have saved $32 \%$ of the inputs to generate the same amount of outputs that they generated. In fact, the Islamic banks could have generated the same amount of outputs produced by using only $68 \%$ of the amount of inputs used. 
Table 3. Descriptive Statistics of Efficiency Scores

\begin{tabular}{|c|c|c|c|c|}
\hline & & Mean & Max & Min \\
\hline \multirow{3}{*}{2006} & OTE & 0.70 & 1 & 0.16 \\
\hline & PTE & 0.73 & 1 & 0.16 \\
\hline & $\mathrm{SE}$ & 1.00 & 1 & 0.70 \\
\hline \multirow{3}{*}{2007} & OTE & 0.60 & 1 & 0.18 \\
\hline & PTE & 0.64 & 1 & 0.12 \\
\hline & $\mathrm{SE}$ & 0.95 & 1 & 0.62 \\
\hline \multirow{3}{*}{2008} & OTE & 0.74 & 1 & 0.30 \\
\hline & PTE & 0.79 & 1 & 0.35 \\
\hline & $\mathrm{SE}$ & 0.93 & 1 & 0.65 \\
\hline \multirow{3}{*}{2009} & OTE & 0.70 & 1 & 0.30 \\
\hline & PTE & 0.77 & 1 & 0.31 \\
\hline & $\mathrm{SE}$ & 0.91 & 1 & 0.60 \\
\hline \multirow{3}{*}{ ALL } & OTE & 0.68 & 1 & 0.16 \\
\hline & PTE & 0.73 & 1 & 0.12 \\
\hline & $\mathrm{SE}$ & 0.91 & 1 & 0.65 \\
\hline
\end{tabular}

OTE= Overall Technical Efficiency; PTE= Pure Technical Efficiency; SE= Scale Efficiency

\subsection{The Determinants of Banks' Efficiency}

Our study will assess the impact of efficiency on a range of different characteristics that may influence the efficiency. After answering our first objective, which consists of computing and analyzing the efficiency score. In this stage of the study, we will regress these scores upon the variables that characterize Islamic banks. Coefficients obtained reflect the direction of influence and the strength of the relationship. Regression results focusing on the relationship between bank efficiency and the explanatory variables are presented in Table 4 . The equations are based on the intermediation approach of 120 bank-year observations during the 2006-2009 periods.

A general overview of Table 4 shows that the explanatory power is potentially high in the estimations $\left(\mathrm{R}^{2}=50.7 \%\right)$ which is a good result for a panel data. Therefore, our model explains the phenomena of Islamic banks' efficiency. Table 4 also shows the results of the association between efficiency and management capability. This result reflects the true nature of the banking activity where a deployment of resources, development and implementation of policies, can aggressively maximize the income and reduce costs. In other words, it affects the banks' efficiency positively.

The results outlined in Table 4 show a negative and significant relation between size and efficiency. In the literature, this relation is a controversial issue. In fact, a group of studies showed that the firm size is related positively to the efficiency, other authors showed a negative relation between the two variables in the context of Islamic banks. El Moussawi \& Obeid (2010) concluded that efficiency is related negatively to the size of banks during the period 20052008 in the context of Islamic banks operating in the GCC. The existing relationship means that a proportion of their inefficiency is probably the result of an inadequate size (Moussawi \& Obeid, 2010).

In Table 4, the dependent variables are bank's efficiency score derived from the DEA Intermediation approach. ASSET_QLT is a measure of asset quality calculated as total loan loss provisions divided by total loans. MGT_QCT is a measure of management capability calculated as operating expenses by Net income. LNTA is the size of the bank measured, as the natural logarithm of total assets. LAR is a measure of liquidity as the ratio of the total loan divided by the total asset. SE_MKT is a proxy measure for sensitivity to market risk calculated off balance sheet items / Total Assets. KA is used to examine the relationship between efficiency and risk-taking propensity. 
Table 4. Panel Regression Analysis

\begin{tabular}{|c|c|c|c|}
\hline Variables & Coefficient & $\mathbf{t}$ & P-value \\
\hline ASSET_QLT & 0.02 & 0.62 & 0.534 \\
\hline MGT_Q̄CT & 0.49 & 7.27 & $0.00^{* * *}$ \\
\hline LNTA & -0.107626 & -2.87 & $0.004^{* * *}$ \\
\hline LAR & 0.854 & 7.87 & $0.00^{* * *}$ \\
\hline KA & .0740141 & 0.76 & 0.450 \\
\hline SE_MKT & -.042397 & -0.37 & 0.712 \\
\hline Const & 0.87 & 3.45 & 0.000 \\
\hline $\mathrm{R}^{2}$ & & 0.5 & \\
\hline No. of Observ. & & 120 & \\
\hline
\end{tabular}

A positive relationship between liquidity and efficiency during the period of study exist. Banks with a large volume of liquid assets are perceived safe since these assets would allow them to meet unexpected withdrawals. These results give the indication that highly liquid assets characterize efficient banks, which supports the findings of Amer (2001). Under the intermediation approach, KA has a positive relationship in the regression model. This relationship is not compelling in determining the efficiency of Islamic banks. The result of our study confirms the previous finding of Yudistira (2003), which states that during the period of study, KA does not affect the efficiency of the 18 Islamic banks included in the sample used.

Finally, The Sensitivity to Market Risks (based primarily on some evaluation factors such as sensitivity to adverse changes in interest rates, foreign exchange rates, commodity prices, fixed assets, etc.) reveals a negative relation to efficiency. However, this relationship is not significant.

\section{CONCLUSION}

The aim of this paper is to apply a two-step methodology to investigate the efficiency analyze and assess the determinants of performance in the Islamic banking sector. The lack of empirical studies, which focuses on the analysis of the determinants of Islamic banks efficiency, propelled this study. We have derived the relative technical efficiencies of the Islamic banking sector by implementing a non-parametric Data Envelopment Analysis (DEA) from 2006 to 2009. The DEA methodology is employed using the constant returns to scale (CRS) and the variable returns to scale (VRS) assumptions to provide measures of technical and scale efficiency.

The results show an important level of dispersion of technical efficiency between banks within the sample (year-toyear). The estimated results show that only two banks are relatively efficient during the analyzed period. The average overall technical efficiency varies from 0.16 to 1 . As expected, a greater number of banks appear efficient under the VRS methodology. Other Several conclusions emerge. We found that the sources of the inefficiency are scale efficiency rather than pure technical inefficiency. In addition, Islamic banks in the sample may suffered from the global crisis of 2007-2008 but performed during the next year of study (i.e. 2009).

Having obtained the efficiency measures, we implemented a panel regression analysis to explain the variation in calculating efficiencies to a set of explanatory variables. These variables were bank size, bank asset quality, management capability, sensitivity to market risks, liquidity, and capitalization. The explanation of the efficiency scores using panel regressions technique offers useful academic findings. Our investigation shows that size has a negative impact on efficiency. This may be explaining by the fact that because they offer multiple Islamic financial services, they may not benefit from economies of scale. Then, we interpret the significance of liquidity as an indication of the higher efficiency of Islamic banks. This means that more liquid banks achieve a higher technical efficiency. The significance of the management capability ratio for explaining efficiency suggests that banks with higher management capability ratio are more efficient since they can understand and respond to the risks associated with their activities and to plan for the future. Finally, sensitivity to market risks, capitalization, and asset quality have either a negative or a positive sign, but they are insignificant. 
Our investigation is not without limitations. In fact, more Islamic banks can be included in the study as well as other input and output variables could be included. However, the findings could help managers to review their policies to increase performance and efficiency. Futures researches may concentrate on analyzing the efficiency of Islamic bank using different approaches than used in this study.

\section{AUTHOR INFORMATION}

O. Nafti has a PhD in business administration (Accounting) from the University of Tunis, Tunisia. Dr. Nafti is assistant professor in the department of Accounting and finance at ISCAE, La Manouba, Tunisia. Dr. Nafti teaches both financial and managerial accounting in undergraduate and graduate levels. Dr. Nafti has been publishing her scientific research in academic journal and made several presentations in several conferences in Tunisia and France. E-mail: olfa.nafti@iscae.rnu.tn

S. L. Boumediene has a PhD in Business Administration (Accounting) from the University of El Manar, Tunisia. Before joining Montana State University-Billings, Dr. Boumediene taught both financial and managerial accounting at both the undergraduate and graduate levels at the top business schools in Tunisia. Dr. Boumediene has been publishing his research work in academic journals, such as the Journal of Applied Business Research and the International Journal of Business and Finance Research, among others. Dr. Boumediene published a book on statistical characteristics and quality of accounting information in 2013. E-mail: salem.boumediene@msubillings.edu (Corresponding author)

S. Khouaja has a PhD in business administration (Quantitative Methods) from the University of Sousse, Tunisia. Dr. Khouaja is an Instructor in the Department of Economics and Quantitative Methods at ESSEC, Business School Tunis, Tunisia. Dr. Khouaja teaches mathematics, statistics and econometrics for undergraduate level and advanced econometrics and polling theory at the graduate level. E-mail: slimkhouaja@gmail.com

W. Ben Ayed is a Ph.D. Candidate in Finance at the High Institute of Management (ISG), GEF-2A Lab, University of Tunis, Tunisia. E-mail: wassim.benayed@isg.rnu.tn

\section{REFERENCES}

Ackermann, P.L.S., Jacobs, E. (2008). Developing banking products for Islamic corporate clientele. Southern African Business Review, 12(1), 67-88.

Ahmad, N.H., Noor, M.A.N. (2011). The Profitability and Determinants Efficiency of World Islamic Banks. Journal of Islamic Banking and Finance, 29(2).

Ariff, M. (1988). Islamic Banking. Asian-Pacific Economic Literature, 2(2), 46-62.

Austay, M., Izhar, H., (2007). Estimating the Profitability of Islamic Banking: Evidence from Bank Muamalat Indonesia. Review of Islamic Economics, 11(2), 17-29

Banker, R.D., Charnes, A., Cooper, W.W., Swarts, J., Thomas, D.A. (1989). An Introduction to Data Envelopment Analysis with Some of its Models and Their Uses in Research in Governmental and Non-profit Accounting, edited by J. L. Chan and J. M. Patton, Greenwich: Jai Press, 125-163.

Casu, B. Girardone, C. (2002). A comparative study of the cost efficiency of Italian bank conglomerates. Managerial Finance, 28(9), 323.

Benston, G. J., (1965). Branch Banking and Economies of Scale. Journal of Finance, 20(2), 312- 331.

Berger A. Humphrey D., (1997). Efficiency of financial institutions: International survey and directions for future research. European Journal Of Operational Research, 98, 175-212.

Brown, K., Skully, M., (2003). A comparative analysis of Islamic bank efficiency. International Banking Conference 2003, Prato, Italy, 9-10 September

Chapra, M. U., (2000). Why Has Islam Prohibited Interest? Rationale Behind the Prohibition of Interest. Review of Islamic Economics, 9 , $5-20$.

Charnes, A., Cooper, W. W., Rhodes E. (1978). Measuring the Efficiency of Decision Making Units. European Journal of Operation Research, 2, 429-444.

Chawki E., Obeid, H., (2010). Evaluating the Productive Efficiency of Islamic Banking in GCC: A Non Parametric Approach. International Research Journal of Finance and Economics, 53, 1450-2887.

Cihajk, M., Hesse, H., (2008). Islamic Banks and Financial Stability: An Empirical Analysis. IMF Working Papers 08/16, International Monetary Fund.

Coelli, T.J., Rao, P., D.S., O’Donnell, C.J., Battese, G.E. (1998). An Introduction to Efficiency and Productivity Analysis. Boston, USA: Kluwer Academic Publishers. 
Darrat, A.F., Can, T., Yousef, T. (2003). Assessing Cost and Technical Efficiency of Banks in Kuwait. Studies in Economics and Finance, 21(2) 1-21.

Drake, L., Hall, M. J.B., Simper, R. (2006). The Impact of Macroeconomic and Regulatory Factors on Bank Efficiency: A NonParametric Analysis of Hong Kong's Banking System. Journal of Banking and Finance, 30(5), 1443-1466.

Farrell, M. J. (1957). The measurement of productive efficiency. Journal of the Royal Statistical Society 120(3) 253-281.

Mokhtar, H.S.A., Abdullah, N., Alhabshi, S.M. (2008). Efficiency and competition of Islamic banking in Malaysia. Humanomics, 24(1), 28-48.

Haron, S., (2004). Determinants of Islamic Bank Profitability. Global Journal of Finance and Economics, 1(1).

Hasan, M. Dridi, J. (2010). Put to the Test Islamic banks were more resilient than conventional banks during the global financial crisis. Finance \& Development December 2010.

Havrylchyk, O. (2006). Efficiency of the Polish banking industry: Foreign versus domestic banks. Journal of Banking and Finance, 30 , 1975-1996.

Hariandy .H, Tendi, H. (2011). Banking: According to Islamic Sharia Concepts and Its Performance in Indonesia. International Review of Business Research Papers 7(1), 60 - 76.

Izhar, H., Asutay, M. (2007). Estimating the Profitability of Islamic Banking: Evidence from Bank Muamalat Indonesia. Review of Islamic Economics, 11(2).

Imam, P., Kpodar, K. (2010). Islamic Banking: How Has it Diffused?, IMF Working Paper, WP/10/195

Iqbal, M. (2001). Islamic and Conventional Banking in Nineties. A comparative study. Islamic Economic Studies, 8(2).

Kablan, S., Yousfi, O. (2011). Performance of islamic banks across the world: an empirical analysis over the period 2001-2008. Retrieved from: http://mpra.ub.uni-muenchen.de/28695/

Hisham, K. B., Samaun, S. M., Rohani, M. (2008). Assessing production efficiency of Islamic banks and conventional bank Islamic windows in Malaysia. International Journal of Business and Management Research, 1, 31-48.

Hassan, K., M., Hussein, K. A. (2003). Static and Dynamic Efficiency in the Sudanese Banking System. Review of Islamic Economics, $14,5-48$.

Karim, M.Z.A. (2001). Comparative bank efficiency across select ASEAN countries. ASEAN Economic Bulletin, 18(3): $289-304$.

Brown, K. (2003). Islamic Banking Comparative Analysis. The Arab Bank Review, 5(2).

Kwan, S. H. (1997). Efficiency of U.S. Banking Firms: An Overview. Federal Reserve Bank of San Francisco Economic Letter, No. $97-$ 06.

Hamim S., M., Abdullah, N., Al-Habshi, S.M. (2006). Efficiency of Islamic Banks in Malaysia: A Stochastic Frontier Approach. Journal Of Economic Cooperation Among Islamic Countries, 27(2), 37-70.

Akbar, M., Noor, N., Ahmad, N.B.T. (2011). The Determinants of World Islamic Banks' Efficiency and the Impact of 1998 and 2008 Financial Crisis. Bangladesh Development Studies Vol. 34(1).

Molyneux, P., Thornton, J. (1992). Determinants of European Bank Profitability: A Note. Journal of Banking and Finance, 1173-1178.

Onour, I., Abdalla, A. (2011). Scale and Technical Efficiency of Islamic Banks in Sudan: Data Envelopment Analysis. Retreived from: http://mpra.ub.uni-muenchen.de/29885/.

Ackermann, P.L.S., Jacobs, E. (2008). Developing banking products for Islamic corporate clientele. Southern African Business Review, $12(1), 67-86$.

Roszaini, H., Hudaib, M. (2010). Islamic finance: from sacred intentions to secular goals? Journal of Islamic Accounting and Business Research 1(2) 85-91.

Saaid Ali, A. E., Rosly, S.A., Ibrahim, M. H., Abdullah, N. (2003). The x-efficiency of the Sudanese Islamic banks. IIUM Journal of Economics and Management, 11(2), 123-41.

Saleh, A.S., Zeitun, R. (2006). Islamic Banking Performance in the Middle East: A Case Study of Jordan. Economics Working Paper Series, University of Wollongong.

Sathye, M. (2003). Efficiency of Banks in a Developing Economy: The Case of India. European Journal of Operational Research, $148(3), 662-671$.

Scheel, H. (2000). Efficiency Measurement System Software (EMS) Ver. 1.3," University of Dortmund.

Sealey, C.W., Lindley, J. T. (1977). Inputs, outputs, and a theory of production and cost at depository financial institutions. Journal of Finance, 32(4), 1251-1266.

Haron, S. (2004). Profitablity determinants of islamic banks: a cointegration approach. Presented at the Islamic Banking Conference, Union Arab Bank, Beirut, Lebanon, 5-7 December 2004.

Sufian, F. (2006). Size and Returns to Scale of the Islamic Banking Industry in Malaysia: Foreign Versus Domestic Banks. IIUM Journal of Economics and Management 14(2), 147-175.

Sufian, F. (2007). The efficiency of Islamic banking industry in Malaysia: Foreign vs domestic banks, Humanomics. The International Journal of Systems and Ethics, 23(3), 174-192.

Sufian, F. Noor., M.A.N.M. (2009). The Determinants of Islamic Bank's Efficiency Changes: Empirical Evidence from the MENA and Asian Countries Islamic Banking Sectors. International Journal of Islamic and Middle Eastern Finance and Management, 2(2), 120-138.

Tahir, I.M., Abu Bakar, N.M., Haron, S. (2009). Evaluating Efficiency of Malaysian Banks Using Data Envelopment Analysis. International Journal of Business and Management, 4(8).

Thanassoulis, E. (2001). Introduction to the Theory and Application of Data Envelopment Analysis: A Foundation Text with Integrated Software. Boston: Kluwer Academic Publishers.

Viverita, K. B., Skully, M. (2007). Efficiency Analysis of Islamic Banks in Africa, Asia and the Middle East. Review of Islamic Economics, 11(2), 5-16.

Yudistira, D. (2004). Efficiency in Islamic Banking: An Empirical Analysis of Eighteen Banks. Islamic Economic Studies 12(1), 1-19. 